\title{
Cancer! Look at the blood
}

\author{
Eda Alemdar* \\ University of Goce Delcev, Faculty of Medicine, Macedonia
}

Received: 眥: September 14, 2018; Published: ${ }^{-1}$ September 21, 2018

*Corresponding author: Eda Alemdar, University of Goce Delcev Faculty of Medicine, Macedonia

\section{Abstract}

Background: Blood is the only substance that exists throughout the human body. Blood is a source of life that feeds whole body and organs to function. According to this, if the blood is healthy; the whole body will be healthy. The aim of this article is to emphasize that blood is the most precursor substance that made a human healthy. At the same time, with drawing attention to the obligation that blood must be healthy, in the case of blood degeneration or loss its features, it is emphasizing carefully that whole body health will fail.

Method: Examination of classical medical data and modern medical researches related to blood, an eclectic approach has been introduced which will fail human health with degeneration of blood. Moreover, treatment methods for solving the mentioned problems have been revealed in this study either.

Result: It emphasized that the treatment of all the illnesses in the body, caused by degenerated blood, is possible by curing the blood. Because many diseases in the human body are caused by the degeneration of the blood. Cancer is also this kind of disease, and its treatment can only be understood by us, by means of blood treatment.

Conclusion: With the degeneration of the blood, the whole body goes bad and diseases emerge. The treatment of this is to ensure that the degenerated blood is expurged and that the body can produce its own blood in a healthy manner.

\section{Background}

The right information, the diagnosis, and the treatment of a disease are only possible with knowing all the factors and data about it in a comprehensive way. Thus, for a healthy treatment, the identification of the causes of the disease and the diagnosis are required. Diagnosing the most effective cause of the disease among multiple causes is essential for a permanent treatment. Because, in the treatment of diseases, a permanent solution can be produced with a holistic approach, considering the relationship between the whole body and the organs. The systems that create the human body are locomotor, neural, respiratory, urinary and circulating systems. In all these systems there are more than one basic and active substances. Blood is the most active substance between these active substances. It is a specialized type of collagen tissue composed of blood, plasma, and cells. Blood is the basic building stone that gives life to the human body. The state of the body's vitality depends on maintaining adequate blood circulation throughout the body. For this reason, blood is the main factor in keeping someone healthy or making one sick. Because of the many tasks of the blood, two main activities attract the attention. The first is the delivery of substances such as needed food to the cells.

The second is the removal of residues from the body. The circulating system in the human body covers the entire body. The basic substance of this system is blood. In this direction, blood feeds all the body and organs from top to bottom and carries all the minerals, vitamins, cofactors necessary for healthy life to the cells, and exists all over the body. So, the blood feeds the whole body. According to this, when the blood degenerated, the entire body is damaged from this. The degeneration of the blood is is caused by food, weather, and environmental factors. The degenerated blood is spread to the entire body and reaches all the organs in a very short time [1]. All the toxic substances in the degenerated blood, from our neurotransmitter in our brain, cause cell destruction in all body organs and cause the death of the cells. The degenerated blood in this direction breaks the balance of the body and begins to damage the entire body by surrounding the normal healthy cells of vital organs.

\section{Discussion}

According to, hemopoiesis describes the formation of blood cells. During embryonic development, the hemopoietic system is sequentially derived from the aorta-gonad-mesonephros part of the mesoderm, the haemangioblast, the hemogenic endothelium and subsequently the hemopoietic progenitors. The liver is important for fetal hemopoiesis. Hemopoiesis in children and adults occurs mainly in bone marrow, with some contribution from other sites. The bone marrow microenvironmental niche and other factors are crucial for regulating hemopoiesis in the face of changing demand [2]. In postnatal life, the production of circulating blood cells occurs in the bone marrow (BM), in the honeycomb spaces of trabecular bone. In the infant and growing child, hemopoiesis takes place in all bones of the skeleton [3]. The fact that this blood is produced, 
especially in the bone marrow, affects the blood-making items as well as all the organs it reaches and its body in that direction.

Because blood-forming organs such as bone marrow, trabecular bone, liver, and spleen are directly linked to each other or to other organs. When these blood-forming organs are sick, and the blood that they produce reaches all other tissues and organs in the body. The blood and the organs that reach them are either healthy or unhealthy depending on the condition of the blood [4]. The human body is standing with food. Blood brings these foods to the whole body. This transportation happens through the veins. According to this, the blood first feeds the heart and the vessels that are spread throughout the body. If the natural features of the blood are lost and the healthy structure deteriorates, the entire body will suffer damage, primarily the heart and veins will be damaged. If the human body's healthy blood is not pumped into the body to enough extent, it will cause unnatural immunological and physical reactions to occur in the different regions of the body. This paves the way for many diseases. Because the real food is blood, which is found in all organs, and which reaches all over the body. In this case, to the organs that the blood does not go, that way the necessary food has not reached to them. This leads to the mentioned organs not being able to feed and then not to perform its task.

Regeneration by the full blood transfusion method for this treatment has some benefits [5] as well as some risks [6]. First, the transmitted blood may carry the risk of infection. In addition to this, a full blood transfusion is effective in the treatment of trauma injuries, but there is a risk of inducing graft versus host disease [7]. In addition, the presence of the product depends on the pre-screened donors that are compatible with the appropriate ABO blood type on the field [8]. Hence, according to a study by Reslo et al. [9] there are risks of blood transfusion, asymptomatic infection state, the prevalence of infection, and blood transfusion and transmission of serious disease. In this study about infectious diseases and blood transfusion, diseases with uncertainty (hypothetical), which vary depending on disease characteristics, are listed and probability distributions are made about these risks. The classical medics, composed of the Greco-Roman Medicus and the Islamic physician, have suggested that one of the best ways of treating the deteriorated health of one person is to drain the degenerated blood in the body, thinking that the degenerated blood will harm the whole body [10]. Because they have suggested that the blood that is added to a degenerated and diseased blood will not remain healthy.

Blood is a vital fluid that carries oxygen, nutrients, hormones, vitamins, antibodies to tissues in the body and excretes carbon dioxide and residual substances in the body. It is a fluid that circulates through the vein network consisting of blood, arteries, veins, and capillaries, and flows from the cells formed by flowable plasma, red blood cells, white blood cells and blood platelets. At the same time, blood is a special juice that changes. Blood, which is fluid in continuous motion, is made up of blood cells. These blood cells are also made up of various forms and plasmas. The plasma remaining in the outer part constitutes $55 \%$ of the blood volume. Plasma consists of $92 \%$ or $90 \%$ of the water. The remaining part consists of elements such as plasma proteins which are organicinorganic substances, amino acids, carbohydrates, fats, hormones, uric acid, urea, lactic acid, enzymes, antibodies and elements such as sodium, potassium, iodine, iron, bicarbonate. With this structureof its, blood is directly connected with nature.

Blood is the main factor in the existence of a human. Hence, the fact that the blood is the basic building stone of human structure is also a subject of the Holy Scriptures. For example, in the Torah, "Blood is life" (Joshua 2/13-14) expresses that blood is the essential element of life. On the other hand, we think that the words in the verses "We created man from a filtered core from the mud" (Al-Mu'minun 23/12) and "God created man from the blood clot" (al-Alaq 2), "filtered core" and "alaq" are representing blood. On the other hand, blood is among the main factors of sperm that make up the existence of human [11]. Indeed, the male reproductive system comes from a system of testicles, channels, and other glands that open through channels. There is blood in this system. The origin of the bones, fat, and meat in the body, which keep the life of the human who came to earth. The tissues, which originated from blood and protect the power of human semen, grow and develop again during childhood. In this direction, blood is the building stone of both the female and the male reproductive organs, as well as the building stone of all humans.

Regarding the formation of the fetus in the mother's womb, Avicenna found the following determination: During normal menstruation, blood drawn out during menstruation is directed towards the development of the fetus during pregnancy [12]. In the words of Avicenna, if the blood of the mother gets sick, the fetus in the mother's womb will be nourished by this blood, so the baby is born ill. According to this, if there is any disease in the blood that pass to the baby, the baby will be sick. If the degenerated blood does not provide nutrition to the baby, the baby will not be healthy. Depending on this situation, diseases occur in the baby. The result from this data is: At the heart of human creation is blood, and the greatest factor on the basis of creation is blood. Excessive red blood cells or blood failure/anemia in the human body can cause the organs to fail to perform their functions properly [13].

However, the biggest problem that can be encountered when the normal amount of blood is needed by the body is that the blood is not natural and clean. It has been accepted that the cleaning of the blood is primarily performed by air [14]. Environmental toxic effects beyond eating and drinking are polluting the blood. Contaminated blood leads to chronic inflammation in the brain as well as heart diseases, as in many other organisms [15]. This causes damage to the brain's neurons, causing many diseases such as Alzheimer's [16]. One of the first centers of action, which clean or dirty, healthy or unhealthy air makes to human beings, is blood [17]. If the air is dirty and bad, it directly reaches the blood and affects the blood negatively [18]. Blood is the basic building stone of the body. Anyone whose blood is clean mostly will have a healthy body. Because blood is the main factor that feeds the whole body [19]. 
Healthy blood is first understood from color, taste, and smell. When the disorder is observed, the diagnose is there is something wrong with blood. In this direction, dark blood has lost its normal properties. This leads to many diseases such as hemorrhoids [20]. Another sign of illness, which has an important place in the determination of human health, is the blood flow rate. Hence, according to a research about diagnosis and detection of diseases by Infrared, Infrared thermal camera detects the heat and infrared radiation generated by blood flow in skin capillaries. The light intensity is directly proportional to the temperature at which the heat is transmitted and the blood flow in the tissue. The changes in photon flow are measured and analyzed to determine the change in blood flow within the tissue. In this direction, you also have information about the physiology of the disease [21]. It is oxygen that gives the blood its natural red color. If this is not enough, the blood loses its natural color [22]. Hence, the most basic cause of death is caused by the problems created by blood and blood itself. According to our observations, the blood of anyone who is about to die is blackening. When someone dies, the color of the blood changes completely.

The blood has its own heat. Blood also balances the heat of the liver and other organs. When blood is insufficient in the body, whole body heat is adversely affected, and this damages the body's health [23]. The blood that is present in the body in the direction of this data is corrupted and the treatment to be performed for the direct organs of a diseased person does not give a lasting result [24]. The biggest bad effect of the degenerated blood on the human body is cancer. Because the most important cause of cancer is the degeneration of blood. Hence, when the blood in the veins breaks down, there is a heat above the natural heat. Depending on this heat, if the blood goes out of the vein, it causes a serious illness. Degenerated blood that flooded through the vein also forms a malignant tumor at the site of its spread [25]. Malignant tumors, when not treated, grow rapidly in the body, and soon overflows beyond the borders of their organ. It especially metastases in distant locations. When it reaches all organs, it puts the patient's life at risk or usually leads to death.

Today, many researches on the blood-cancer relationships are carried out [26]. In these researches, the relationships between blood and cancer have been examined through ways of spreading cancer to the body. In this direction, the tumor spreads to the body in three ways (metastasis). These are transcoelemic, lymph glands, and blood circulation. These three channels are also directly related to blood. It is known that our body is covered with blood vessels. Cancer cells reach the organs with blood vessels. Hence prostate cancer makes metastasis to bones; cancer of the colon and digestive system to the liver and lung. This is usually through blood [27]. Besides, the heart sends the blood that comes to it to the lungs. Therefore, cancer cells reaching the heart are more likely to metastasize to the lung. These cells are transformed into small malignant tumors in the organs they reach (micrometastasis). These then complete the formation of metastases and turn into large tumors [28]. However, many types of cancer, such as metastatic cancer, cancer cells located in the liver and lung, are also located in other tissues and organs that the blood reaches. Thus, the organs of the body, especially organs and tissues, are always at risk of having cancer.

Since malignant tumors have access to nutrients via blood, they continue to grow. As they grow, the cells can be separated and transported to the whole body through blood. Metastases are formed when these cells are placed in other tissues by circulation. On the other hand, the blood of patients in advanced stages of cancer has changed color due to lack of iron carrying oxygen-hemoglobin. In a patient's blood, who caught cancer because of toxic substances, radiation and acidosis, pharmaceuticals and malnutrition; wastes such as carbon dioxide take place of the oxygen. According to the Nobel Prize-winning Otto Warburg, these oxygen deficiencies cause the formation of tumors. In this case, the cells mutate to obtain energy from a sugar fermentation process. This causes more acidosis and cellular oxygen starvation. Eventually, the process causes cancer cells to multiply and give fatal results [29].

\section{Conclusion}

In the way of our study, blood is the basic life tool of the human body. It is the blood that makes people live. Because blood is life. The main substance (alaq) in the first creation of man is also blood. The health of the body is directly related to the health of the blood. According to this, the blood is unhealthy and degenerated, which means that the whole body is diseased. The treatment of diseases found in the body and organs should be initiated primarily with the treatment of blood. By cleansing the blood, the whole body is cleaned from the diseases that are connected to it, and it is in serious condition that it is regained health. In this direction, we believe that the treatment of cancer is also directly related to the cleanliness of the blood and the healthy blood. Because the main cause of cancer is the degeneration of blood. Accordingly, the treatment of the cancer patient is possible by clearing his blood.

The body gets rid of many diseases when the degenerated blood is thrown out of the body. In the place of evacuated the blood making blood transfusions from outside has serious problems. Full compliance or illness of the blood, which got from outside, is one of them. The most permanent solution is to ensure that the blood-producing organs are actuated and that the body produces its own blood, in its own direction, itself. This is the main point. The tissues that the blood does not reach are blocked. In this case, these tissues, which the blood does not reach, cannot perform their duty properly. The human body can be constantly renewed. Accordingly, if blood in the dysfunctional tissues reaches as much blood as the cells, the cells may move, and tissues and organs may begin to function again. Accordingly, the underlying cause of all diseases is blood lack in organs and tissues or the existing blood's degeneration. The cells and tissues, that blood does not reach, start to damage in time. Later, in places where these tissues are present, mutations and diseases occur.

By cleaning up the degenerated blood and then renewing the blood, we think that the apoptosis process in the human body will accelerate and the tumor cells will get out of the way and the healing 
process will accelerate. Because when the blood degenerated, the apoptosis process is also degenerating. On the other hand, the cornea is the only one fed by the oxygen it takes from the air not fed with blood. While every tissue and organ that the blood reaches are at risk for cancer, there is no risk of developing cancer in the cornea. Because there is no blood in the cornea. And this situation supports our thesis of "the biggest cause of the formation of cancer, degenerated blood". Our work is of original quality and is a structure that will shed light on the work will be done in this area. It will contribute to applied research to be carried out by experts of the field. Our theses in this study provide theoretical information for future research. We believe that these data will be the source of future scientific studies.

\section{Acknowledgement}

The author sincerely thanks Tahir SANCAR, M. Hakan SANCAR and Prof. Dr. Ramazan BICER for their kindly contributions.

\section{References}

1. Ibn Al Nafis, A al Mucaz Fi al Tib (1986) Cairo: Ministry of Culture publications p. 277.

2. Patel A, Radia D (2017) Hemopoiesis - the formation of blood cells. Clinical Science 45(4): 194-197.

3. Smith TG (2013) Hemopoiesis - the formation of blood cells. Clinical Science 41(4): 200-203.

4. Fuad M (1928) Kan ve Aza-yı müvellidü dem hastalıkları. Istanbul: Hüsn-ü tabiat Matbaası p.78.

5. Ryniak S, Harbut P, Goździk W, Sokołowski J, Paciorek P, et al. (2011) Whole blood transfusion in the treatment of an acute organophosphorus poisoning - a case report. Med Sci Monit 17(9): 109-111.

6. Cerhan JM, Cerhan JR, Wallace RB, Folsom AR, Potter JD, et al. (1993) Transfusion history and Cancer risk in older women. Annals of Internal Medicine 131(1): 8-15.

7. Femke N, Thijs TCF, Van D, Mari CJ, Plat JF B, et al. (2016) Transfusion: $-80^{\circ} \mathrm{C}$ Frozen Blood Products Are Safe and Effective in Military Casualty Care. PLOS ONE p. 1-18.

8. Resar MSR, Frank SM (2014) Bloodless medicine: what to do when you can't transfuse. America Society of Hematolgy 1: 553-558.

9. Neslo REJ, Oei W, Janssen MP (2017) Insight into 'Calculated Risk': An Application to the Prioritization of Emerging Infectious Diseases for Blood Transfusion Safety. Risk Analysis: An International Journal 37(9): 1783-1795.

10. Razi EB (2013) Tabibin ahlakı ve bir saatte şifa. Istanbul: Zeytinburnu municipal publications p. 41-42.

11. Ibn Serif Yadigar (2017) Istanbul: Zeytinburnu municipal publications :80; Bergamo P, Volpe MG, Lorenzetti S, Mantovani A, Notari T, et al. (2016) Human semen as an early, sensitive biomarker of highly polluted living environment in healthy men: A pilot biomonitoring study on trace elements in blood and semen and their relationship with sperm quality and RedOx status. Reproductive Toxicology 66: 1-9.
12. Ibn Sina EA (2017) Al-Kanun fi't-tıb. Trns in Turkish, Esin Kahya. Ankara: Ataturk Culture Centre Publications 1: 39.

13. Ibn Serif (2017) Yadigar, Istanbul: Zeytinburnu municipal publications p. 91.

14. Mamon MB, YY Osmanli tabibi Musa B, Mamon (2012) AZ Izgoer. Istanbul: Zeytinburnu municipal publications p. 32.

15. Vlaanderen JJ, Janssen NA, Hoek G, Keski RP, Barupal DK, et al. (2017) The impact of ambient air pollution on the human blood metabolome. Environmental Research. Environmental Research 156: 341-348.

16. Chen YP, Liu Q, Ma Q, Maltby L, Ellison AME, et al. (2018) Environmental toxicants impair liver and kidney function and sperm quality of captive pandas. Ecotoxicology and Environmental Safety 162: 218-224.

17. Ibn Sina EA (2017) Al-Kanun fi't-tıb. Trns in Turkish, Esin Kahya. Ankara: Ataturk Culture Centre Publications 1: 160.

18. Erzurumlu IH (1980) Marifetname Istanbul: Bedir Publications. p. 362.

19. Razi AB (1981) Al-Madhal Al-Sagir ila Ilmi't-Tibb (in Sittu resail mine'tturas All-Arabi al-Islami). (EdS.) AM. el-Abd. Cairo: Mektebe Nehda alMisriyya p. 106.

20. Ibn Kamal, Kamaliya (2007) AH Bayat. Istanbul: Zeytinburnu municipal publications p. 87.

21. Düzgün D, ME OR (2009) Termal kameraların tıpta veteriner hekimlikte kullanımı. TÜBAV Bilim Dergisi 2(4): 468-475.

22. Watchman H, Walker GS, Randeberg LL, Langlois NEI (2011) Reoxygenation of post-mortem lividity by passive diffusion through the skin at low temperature. Forensic Sci Med Pathol 7(4): 333-335.

23. Mazlomi A, Golbabaei F, Farhang D, Abbasinia M, Mahmoud K, et al. (2017) The influence of occupational heat exposure on cognitive performance and blood level of stress hormones. International Journal of Occupational Safety and Ergonomics 23(3): 431-439.

24. Razi EB (2013) Tabibin ahlakı ve bir saatte şifa. Istanbul: Zeytinburnu municipal publications p. 38.

25. Tabari, Ali b, Rabban (2002) Firdaws al-Hikmah fi't-Tıb. Beirut: Dar alKutub al-Ilmiya p. 208.

26. Barry KH, Moore LE, Sampson JN, Koutros S, Yan L, et al. (2017) Prospective study of DNA methylation at chromosome 8q24 in peripheral blood and prostate cancer risk. British Journal of Cancer 116(11): 1470-1479.

27. El Hajj II, Baz EMK, Abdulbaki H, Sharara AI, Hashash JG (2007) ABO Blood Group and Gastric Cancer: Rekindling an Old Fire? Southern Medical Journal 100(7): 726-727.

28. Roberts S, Jonasson O, Long L, McGrew EA, McGrath R, et al. (1962) Relationship of cancer cell in the circulating blood to operation. Cancer 15(2): 232-241.

29. Özgün A, Karagöz B, Bilgi O, Alacacioğlu A, Tunçel T, et al. (2010) Nonsmall cell lung cancer diagnosed with the aid of cardiac metastasis in a breast cancer patient: a case report. Gülhane Tip Dergisi 52(2): 131-133.

30. Warburg O (1966) The Prime Cause and Prevention of Cancer p. 1-14. 


\section{ISSN: 2574-1241}

DOI: $10.26717 / B J S T R .2018 .09 .001768$

Eda Alemdar. Biomed J Sci \& Tech Res

(c) (i) This work is licensed under Creative

Submission Link: https://biomedres.us/submit-manuscript.php

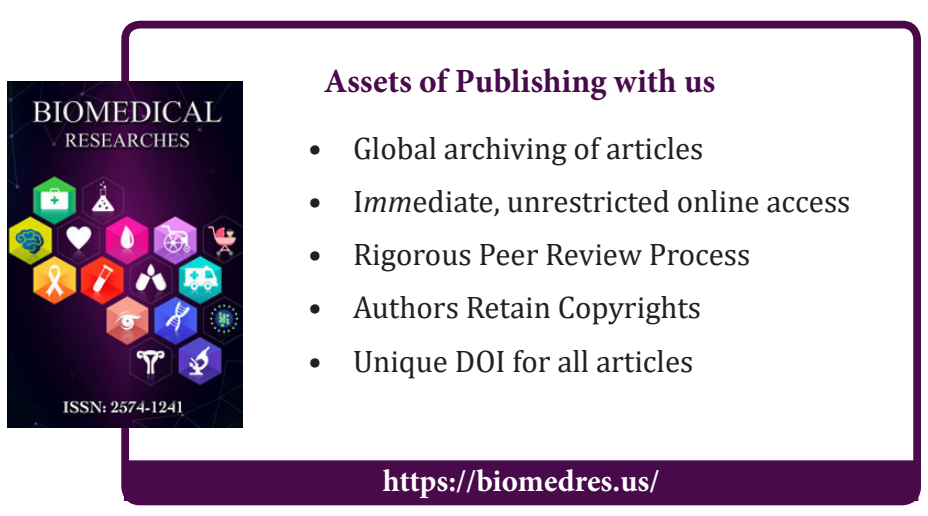

